SECTION: PSYCHOLOGICAL ADVICE AND PSYCHOTHERAPY РОЗДІЛ: ПСИХОЛОГІЧНЕ КОНСУЛЬТУВАННЯ ТА ПСИХОТЕРАПІЯ

УДК 159.9:615.851

DOI: $10.26565 / 2410-1249-2019-12-01$

\title{
SYMBOLS AND IMAGES IN THE MODALITY OF SYSTEMIC FAMILY PSYCHOTHERAPY
}

\author{
Alla M. Lisenaya \\ V. N. Karazin Kharkiv National University, \\ 6, Svobody Sq., Kharkiv, 61022, Ukraine \\ E-mail:lisenaya301163@gmail.com,https://orcid.org/0000-0001-9496-0253 \\ Eugene V. Liseniy \\ V. N. Karazin Kharkiv National University, \\ 6, Svobody Sq., Kharkiv, 61022, Ukraine \\ E-mail:liseniy.evgeniy@gmail.com,https://orcid.org/0000-0002-9031-9060
}

\begin{abstract}
The problem of psychotherapeutic work with symbols and images in the popular in modern conditions method of systemic family constellations, founded by Bert Hellinger, is considered in the article. Psychotherapeutic work in this method covers the content of the unconscious at three levels: personal, generic and collective unconscious. Each of these levels has its own specific symbolism, understanding of which should be possessed by a psychotherapist working in this area of psychotherapy. One of the fundamental mechanisms of the systemic family constellations method is the work with symbols and images that reflect certain mental structures. In the process of conducting a psychotherapeutic session, the client or the substitutes during group work experiences arise that reflect the dynamics in the unconscious structures of the psyche of the client. Similarly with other methods, the language of the unconscious client is reflected through symbols, images, fantasies, metaphors, on the basis of which the therapist builds a session strategy. In the method of systemic family constellations, much attention is paid to the interconnections between the structures of the psyche, which B. Hellinger calls the "orders of love." The orders of love are those laws and patterns on the basis of which the relationships between the structures of the human psyche are built. These relationships can be in a normal state, and then a person feels holistic and integrated and they can be broken, and this causes symptoms or problems. B. Hellinger singles out many similar connections or "orders of love" in the human psyche. The main "orders of love" and their violations arise in the relationship between parents and children, between husbands and wives, brothers and sisters, men and women. Symptoms, as a rule, symbolically reflect the contradiction between inner experiences and behavior, for example, inner experience is based on the rejection of someone, while outwardly this is not demonstrated. Working with a problem or symptom in the method of systemic family constellations, the therapist seeks to eliminate this contradiction and thus transform the negative relationship (the order of love) into a constructive one. Symbols of constructive relationships are feelings of respect and acceptance for other people.
\end{abstract}

KEYWORDS: systemic family constellations, unconscious, symbols, metaphor, orders of love, insight, emotional response.

One of the most popular methods of family psychotherapy in Ukraine in modern conditions is the method of systemic family constellations, founded by German psychotherapist Bert Hellinger. The popularity of this method is related to the specifics of our mentality. The method of systemic constellations is visual, accessible, emotional, well accepted by our compatriots. Psychotherapeutic work in this approach is aimed not only at the personal unconscious, but also at the tribal structures, which are part of the tribal or collective unconscious. In the literature, various authors offer different versions explaining the principles and mechanisms of systemic family constellations method (Wilfried de Philippe, Gunhard Weber, Franz Ruppert, Ursula Franke, Stefan Hausner, Jan Jacob Stam and others).

From our point of view, one of the fundamental mechanisms of the method of systemic family constellations is the work with symbols and images that reflect certain mental structures. In the process of conducting a psychotherapeutic session, the client or the substitutes during group work experiences arise that reflect the dynamics in the

(C) Alla M. Lisenaya, Eugene V. Liseniy, 2019 
unconscious structures of the psyche of the client. Substitutes, acting out the roles assigned to them, endure the symbolism of reflection of those processes that occur in the unconscious client with the help of bodily manifestations, phrases, emotional states and reactions. As well as when working with other methods, the language of the unconscious client is reflected through symbols, images, fantasies, metaphors, on the basis of which the therapist builds a session strategy.

In the method of systemic family constellations, much attention is paid to generic structures, which include both parent structures (mother and father), and structures of the rest of the genus. The relationship between these structures B. Hellinger calls the "orders of love." The orders of love are those laws and patterns on the basis of which the relationships between the structures of the human psyche are built. Hellinger identifies many such laws and "orders of love." For example, the main "orders of love" in the relationship between parents and children include the following:

1. "Parents give, and children take." Nonequivalent relationships between parents and children. Parents give their children what they themselves received from their parents and what they as a couple take from each other. Children accept their parents as parents and everything that parents give them (introjects, value system, unconscious messages). Later, the children pass on what they received from their parents, first of all, to their own children.

2. Everyone, who takes, respects the gift he received and the person from whom he received it. This "order of love" applies to the relationship between brothers and sisters

3. The hierarchy, according to which parents have priority over children, and the first child over the second [Hellinger, 2010, p. 55-56].

The "orders of love" in the relationship between parents and children should be based on the principle of unconditional respect from the children to their parents, whatever they may be. And parents, in turn, must accept their children as they raised them. In this case, we are talking more about the external manifestations of the relationship between parents and children. However, such external manifestations will just be built on the foundation of the inner experiences that a person feels in contact with his parents. If the inner experience is based on the rejection of its parent, while this is not externally demonstrated, a contradiction arises between the inner experiences and behaviour, which may be reflected in the symptom or problem.

An interesting feature of the manifestation of "orders of love" is that the connection between the structures of the psyche, in this case between parent and child structures, will always exist, regardless of what kind of relationship is built between the person and his parents, whether he knows his parents or he knows nothing about their existence. Even in orphans, in the unconscious, there is this connection between parent and child structures. This connection will always exist. The main violation of these relations is the nature of their construction. Namely, if the connection between parent and child structures is not based on respect and acceptance, the unconscious finds a way to maintain this connection with the help of other emotions and relationships that were more acceptable at that time for a person. Thus, the phenomenon of "loyalty to family members" is known in the method of systemic family constellations appears. For example, in a family of an alcoholic a son is born, who subsequently begins to experience various kinds of dependence, from alcohol, gambling, drugs, etc. In the method of systemic family constellations, this relationship of son and father will be explained by the phenomenon of loyalty. This will be manifested in the fact that no matter how the son does not relate to his father during his life, he will somehow keep in touch with him, his "order of love", because on an initially unconscious level, children always love their parents, surely.

However, if in adulthood a son does not accept his father because of his dependence, on an unconscious level, another connection is formed through loyalty to his father, which in metaphorical language reads as follows: "I am the same as you and to demonstrate this to you, I will repeat your fate." The problem of dependence on the son will clearly show him the reason, namely the rejection of the father as he is, and the lack of respect for him. Through his dependence, the son shows loyalty to his father, i.e. in solidarity with him, repeats his fate. Thus, the connection remains at an unconscious level between the structure of the father and son.

On the other hand, a manifestation of the son's loyalty to his father is the preservation of his mother's connection with her husband. One of the 
possible causes of this problem may be the rejection by his wife of men and the male structure of the psyche. Due to the fact that the nature of acceptance, on the basis of which connections (orders of love) are built, must be unconditional, a woman is given what she most cannot accept in a man. In our case, alcoholism. Living with such a husband, she learns to accept him unconditionally, even if he has the worst vice in her mind. However, if she does not succeed, the son, through loyalty to his father, also stimulates the mother to unconditional reception by his example. The fact is that the mother loves the child unconditionally, and since the son is also a representative of the stronger sex, through unconditional love for his son, who has the same problem that the father learns to accept men unconditionally. In a metaphorical language, the son says to his mother: "I am the same as my father, and to demonstrate this to you, I will repeat his fate."

Working with this problem in the method of systemic family constellations, the therapist seeks to transform this connection (order of love). Firstly, the therapist leads the client to unconditional acceptance and respect, for the son - his father, for his mother his husband. Secondly, when working with son, the therapist changes the nature of the manifestation of the connection (the order of love), through a resolving phrase of the type: "I am the same as you. But I have my own destiny, which is destined for me. I respect you as a father and accept the life that you have chosen for yourself. And no matter what happens, I will always love you as my father."

In this case, the client must come to a true unconditional acceptance, which is fundamentally different from patience and humility. When a person accepts something or someone, of course, he does not need to endure it or put up with it. Unconditional acceptance can be born out of humility and patience, but patience and humility are not the experiences on the basis of which harmonious "orders of love" are built, and to which the therapist must lead the client.

B. Hellinger refers to the main "orders of love" in the relationship between spouses the following:

1. "A man wants a woman for a wife, and a woman wants a man for a husband." If one wants to be paired with the other for some other reason, for example, for the sake of selfish pleasure or material security, then the foundation of such relations is unstable.
2. "A man and a woman together are oriented toward the third, and only in the child does their masculine and feminine achieve their fullness." All that is admired and loved by the husband and wife in themselves and in the partner, they admire the same and they love the same in their child. And all that annoys them and interferes with them in themselves and in their partners, annoys and interferes with them in the child. Therefore, what parents do in terms of respect, love, and help in relation to the partner, they manage in relation to the child. And everything that they fail in terms of respect, love and help in relation to the partner, they fail in relation to the child. An example of the action of this "order of love" is described in the previous example.

3. "A man, loving, takes and cognizes a woman, and a woman, loving, accepts and cognizes a man".

4. An exchange occurs between a man and a woman in which both give and take equally since each of them has what the other does not have, and each does not have what the other has.

5. The "order of love" between a man and a woman is that the wife follows the husband. This means that she follows him to his family, to his locality, to his circle, to his language, to his culture and agrees that the children also follow their father [Hellinger, 2010, p. 67-74].

Knowledge of the "orders of love" in a symbolic form is passed from generation to generation through traditions, cultural values, social norms and moral norms. For example, in modern Slavic culture, they are more negative about the fact that having married a woman, a man goes to live in her family with her parents. Whereas, if in this case a woman lives with her husband with his parents, this fact is perceived more loyally. The answer to this is the unconscious sense of people that one of the "orders of love" is violated, namely, the order that the wife follows the husband.

Another example of the manifestation of "orders of love" in traditions is the tradition of memorial day. The preservation of this tradition provides people with the restoration of communication with previous generations, which consists in the fact that everyone has a place in the patrimonial system, and no one should be forgotten. The performance of this ritual from a psychological point of view is primarily necessary for the person who carries it out, because, thus, he harmonizes the connections in his unconscious and preserves the "orders of love." 
In the method of systemic family constellations, much attention is paid to the rituals of psychotherapeutic work. The most common of these are role assignment and conclusion from them, as well as bowing rituals. The fact is that the ritual of assigning roles can actually be skipped in psychotherapeutic work. Moreover, experienced substitutes, as a rule, do not need to carry out this procedure. The main task of assigning a role is to strengthen the existing dynamics in the group, and especially the dynamics of transfer processes. Contrary to many popular opinions about a certain magical power that is present in the process of conducting a constellation session, this method uses the same mechanisms of group dynamics as in psychoanalysis, gestalt therapy, psychodrama, and other areas of psychotherapy. The same transfer mechanisms operate here, only in contrast to other areas, in systemic family constellations, as in some types of psychodrama, the transfer effect is artificially formed using the role assignment ritual. That is why there is always the possibility of replacing substitutes with other members of the psychotherapeutic group.

Another common ritual is bowing. In this context, the bow symbol in the method of systemic family constellations means a tribute to the bowing to someone. Moreover, a bow, like other rituals, strengthens the dynamics of the therapeutic process by adding such a psychotherapeutic effect as a bodily response. Not only a tribute of respect can be expressed in the bow, but also the acceptance of what the figure standing before the bowing symbolizes.

The main part of the work in the method of systemic family constellations is the interaction between group members. A member of the group with whom psychotherapeutic work is carried out selects and assigns roles to other members of the group, who at that time were called "substitutes." If we imagine the unconscious in the form of a combination of various kinds of structures, for example, the parent structure, the structure of "I", etc., then the role of the substitutes will be to reflect the processes that occur in these structures, as well as the nature of building bonds (orders of love) between them. In this case, substitutes can win back any structures of the unconscious client, even such as structures of long-dead relatives, or relatives so distant that the client may not even know about their existence, etc. In fact, at this moment we are working with the structures of the unconscious client, while the substitutes mirror the processes taking place in him. This is confirmed by the possibility of holding a session of systemic family constellations individually, using figures, toys, metaphorical cards and photographs, simple inscriptions on leaflets, etc. as substitutes. With such work, due to the lack of live feedback from other members of the group, the role of symbols and images greatly increases. In other words, the symbolism of those figures or pictures with which the therapist works will be a source of additional information when constructing hypotheses for identifying and decoupling systemic entanglements.

One of the most common methods in therapeutic practice is the use of toys. In this case, each individual toy can carry its own special context for each client. However, some similar patterns can be distinguished. For example, if there are fabulous characters in the set of toys, and the client selects them for work. In this case, it is necessary to deal with the history and characteristics of that fairy-tale character that the client has chosen.

Example: Princess Fiona from the cartoon "Shrek", can mean an unconscious or conscious desire for reincarnation, the restructuring of psychological mechanisms. Moreover, this may indicate an intrapersonal conflict, which is characterized by the unresolved issue of what form it is in. In other words, how to be a client in life, what role to play. This was the main conflict of Fiona and her main property in the cartoon.

Another clear symbol is the size of the toy that the client chooses. The size of the toy, as a rule, may indicate a perception of the size of the problem. As a rule, the figure that represents the client's problematic request or is directly related to this problem will be selected large and, as the therapeutic work progresses, it can change to a smaller one, or even disappear from the playing field. Whereas the client's choice of a small figure against the background of the rest identical to it, can speak either of the undeveloped structure of the unconscious, which should be updated and developed. Or that this structure is not significant for the client at a given time. For example, a small figure (toy) is chosen for the role of the father, while the figure of the mother in the playing space occupies a large place. This may indicate the excessive importance of the 
maternal structure and the lack of value in the paternal etc.

When working in a modality of systemic family constellations, an important part is occupied by the geometry of space, with the help of which the therapist receives information about the nature of the construction and the connections in the structure of the unconscious client. The analysis of relations is carried out by positioning one substitute in space in relation to another, as well as those actions and conversations that he carries out. For example, the position of one substitute in relation to another in front or behind may show the nature of parent-child relations. Front position the children's position, the position of the future. The back position is the parent position or the position of the past. The position on the right is a man, leading position, a position of strength and external interaction with the outside world. The position on the left is the position of women, emotional, the position of the internal position in relation to the outside world. Positions from top to bottom can also be positions of dominance and submission, positions of senior and junior, positions of self-awareness.

In the process of working with the client at the stage of requesting and assigning roles, the therapist builds hypotheses regarding which systemic disorder is present in this topic and from which kind it comes. Therefore, relatives with difficult fates and all kinds of violations (alcoholics, drug addicts, people with disabilities, killers, suicides, mentally ill, unborn and aborted children, etc.) are in a special spectrum of attention for the therapist. Moreover, during therapy, attention should be paid to the following three levels of systemic disorders or violations of the "orders of love."

The first level includes all those members of the family who were treated unfairly, or relatives with difficult destinies. This level of violation is considered the easiest, since a person who has overcome certain difficulties in the theory of systemic constellations has already worked through his injuries. However, this violation can also have negative consequences for the family and future generations, which will most often be manifested through "loyalty" to members of the clan.

The second level of violations includes all those members of the family who have ceded their place to others in the system. For example, former partners, ex-wives and spouses, etc. Violation at this level can be manifested in disrespect by new partners of previous ones. Surprisingly, but on an unconscious level, this is exactly what can cause a conflict between new partners.

The third level of violations includes all those members of the family who benefited from someone's misfortune. In this case, we are dealing either with those members of the family who often offended others (members of the clan or strangers), or those who received some advantage in life due to the suffering or death of another person. For example, in the case of hostilities, a soldier who kills the enemy, thereby preserving life for him, refers to this level of violations.

During the constellation, the therapist has a number of tools that can be used in working with the client.

The first tool is the collection of feedback from substitutes and its processing. It is carried out as follows. After the substitutes have started an arbitrary movement, the therapist can ask questions at two levels. All of them are aimed at revealing the emotional state of substitutes, thus, all such issues have the same task.

At the first level, the therapist asks the substitute how he feels. If the substitute is rather empathetic and has extensive experience with constellations, he will, as a rule, be absolutely able to formulate his feelings and sensations. However, if the substitute does not have much experience in therapeutic work, or if he encounters his own protective mechanisms, the therapist may experience a lack of feedback. In this case, it is necessary to ask the simplest questions about feelings of self, each time clarifying them. The first questions may be: "What do you feel in the body?", "Is it a comfortable or uncomfortable feeling?" Body-tactile sensations are the most understandable and simple level for a person, since he always feels something at the level of the body, for example, is it cold or warm at the moment. At the same time, we immediately note that in therapeutic work the feeling of cold and heat is not related to the actual temperature in the room. After the substitute has been able to formulate his bodily sensations, the therapist can return him to an emotional level, for example: "What do you feel when you are cold? What kind of emotion do you have? "Thus, at the first level of receiving feedback, the therapist focuses on individual emotional feelings. 
At the second level, the therapist focuses on the relationship between the substitute, formulating and putting together a picture of the emotional connections between them. In this context, the following questions may be raised: "What do you feel about the other substitute?", "What would you like to tell him to do or do?", "Do you want to get closer to him or move away?"

Thus, collecting feedback from substitutes, the therapist builds a system for himself in the head, tracking the internal feelings of the substitutes and the relationship between them. Based on this systematization, a violation hypothesis is formulated. In this case, everything that contradicts the "order of love" in the system will be a violation that you can work with, namely the lack of respect and acceptance, the lack of communication between substitutes, acute emotional reactions, as well as destructive emotional states, such as resentment, guilt, fear, aggression, etc.

Having formulated the hypothesis of the problem, the therapist proceeds to search for a solution and decoupling the systemic interweaving. Working with a client, the therapist can use three main tools:

1. Awareness of the problem. The consequence and confirmation of awareness of the problem and its cause is insight.

2. Emotional response or abreaction, the confirmation of which is catharsis.

3. The acquisition of the value or meaning of traumatic experience, the consequence and confirmation of which is internal acceptance.

It should be noted that these tools in therapeutic work can be used in absolutely any order or not used at all. If we are dealing with a client who needs to understand the cause of the problem, it is not at all necessary to lead him to a catharsis, which in this case may not happen. If in practice we encounter acute trauma, then abreaction is very important, especially if this trauma was not responded at the time of trauma. As for the third tool, giving the meaning is the final stage when the client realizes that there is something resourceful in his injury.For example, this problem or trauma led to the formation of his willpower, or its value may be that, despite the difficulties that the client went through, he managed to cope with them, etc.

\section{Conclusions}

1. Psychotherapeutic work in the method of systemic family constellations covers the content of the unconscious at three levels: personal, generic and collective. One of the fundamental mechanisms of this method is the work with symbols and images that reflect certain structures of the psyche.

2. The method used the same mechanisms of group dynamics as in psychoanalysis, gestalt therapy, psychodrama, and other areas of psychotherapy. The same transfer mechanisms operate here, only in contrast to other directions, in systemic family constellations, the transfer effect is formed artificially using the role assignment ritual.

3. In the method of systemic family constellations, much attention is paid to "orders of love" - these are the laws and patterns on the basis of which the relationships between the structures of the human psyche are built. These relationships can be in a normal state, and then a person feels holistic and harmonious and can be broken, which causes symptoms or a problem.

4. Lack of respect and acceptance, lack of communication between substitutes, acute emotional reactions, as well as destructive emotional states, such as resentment, guilt, fear, aggression and others are violations of the relationships between the structures of the psyche (orders of love), with which you can work.

5. The main part of the work in the method of systemic family constellations is the interaction between the members of the group. If we imagine the unconscious in the form of a combination of various kinds of structures, then the role of "substitutes" will be to reflect the processes that occur in these structures, as well as to reflect the nature of the construction of connections (orders of love) between them.

6. Symbols and metaphors, as well as the geometry of the space with which the therapist works, are a source of information in constructing hypotheses for identifying and decoupling systemic disorders, as well as in restoring the connections (orders of love) between the structures of the psyche.

7. Three main tools are used in the method of systemic family constellations: awareness of the problem (the consequence and confirmation of which is insight), emotional response and the acquisition of the value or meaning of traumatic experience (the result and confirmation of which is internal acceptance). 


\section{REFERENCES}

Hellinger B. (2010). Love of the Spirit. What leads to it and how it succeeds, Moscow: Institute of Consulting and System Solutions, 328.

Hellinger B. (2001). The orders of love: the resolution of family-systemic conflicts and contradictions, Moscow: Publishing House of the Institute of Psychotherapy, 400.

Hellinger B., Gabriele Ten Hevel. (2009). The Long Way. Conversations about fate, reconciliation and fortune, Moscow: Institute of Consulting and System Solutions, 167.

Hellinger B. Thought. (2008). Their roots and their influence, Moscow: Institute of Consulting and System Solutions, 192.

Kuchera I., K. Shaffler. (2007). What is the matter with me? Symptoms of diseases and family placement. Moscow: Institute of Consulting and System Solutions, 157.

\section{СИМВОЛИ ТА ОБРАЗИ В МОДАЛЬНОСТІ СИСТЕМНОӤ СІМЕЙНОЇ ПСИХОТЕРАПІЇ} Лісеная А. М., Лісений Є.В.

Харківський національний університет імені В. Н Каразіна пл. Свободи 6, Харків, 610022, Украӥна

У статті розглянута проблема психотерапевтичної роботи з символами та образами у популярному в сучасних умовах методі системних сімейних розстановок, засновником якого є Берт Хеллінгер. Психотерапевтична робота у даному методі охвачує зміст несвідомого на трьох рівнях: особистому, родовому, колективному несвідомому. Кожен рівень несвідомого має свою символіку, розуміти яку повинен психотерапевт, який працює в даному напрямку психотерапії. Одним з основних механізмів роботи в методі системних сімейних розстановок $є$ робота 3 символами та образами несвідомого, які відображають певні структури психіки. В процесі проведення психотерапевтичного сеансу у клієнта або його заступників у випадку групової роботи виникають переживання, які відображають динаміку несвідомих структур психіки клієнта. Аналогічно з іншими методами, мова несвідомого клієнта відображується через символи, образи, фантазії, метафори, на базі яких психотерапевт формує стратегію сеансу. При роботі в методі системних сімейних розстановок велику увагу приділяють взаємозв'язкам між структурами психіки, які Берт Хеллінгер назвав «порядки любові». Порядки любові - це ті закони та закономірності, на базі яких формуються взаємозв'язки між структурами психіки людини. Такі взаємозв'язки можуть бути нормальними, і тоді людина почуває себе цілісною та гармонійною, а можуть бути порушені, що викликає симптоматику або проблему. Берт Хеллінгер виділив у психіці людини безліч таких взаємозв'язків та їх порушень. Основні порушення у «порядках любові» виникають у стосунках між батьками та дітьми, сестрами та братами, чоловіком та жінкою, подружжям. Симптоми, як правило, символічно відображають протиріччя між внутрішніми переживаннями та поведінкою, наприклад, внутрішнє переживання стосується неприйняття кого-небудь із оточення, хоча на рівні поведінки це не демонструється. Працюючи з симптомом або проблемою методом системної сімейної психотерапії, терапевт намагається усунути подібне протиріччя і таким чином трансформувати негативний зв'язок (порядок любові) у конструктивний. Символами конструктивних зв'язків $є$ почуття поваги та прийняття інших людей.

КЛЮЧОВІ СЛОВА: системні сімейні розстановки, несвідоме, символи, метафора, порядки любові, інсайт, емоційне відреагування.

\section{СИМВОЛЫ И ОБРАЗЫ В МОДАЛЬНОСТИ СИСТЕМНОЙ СЕМЕЙНОЙ ПСИХОТЕРАПИИ}

Лисеная А.М., Лисеный Е. В.

Харьковский национальный университет имени В. Н. Каразина пл. Свободы 6, Харьков, 61022, Украина В статье рассмотрена проблема психотерапевтической работы с символами и образами в популярном в современных условиях методе системных семейных расстановок, основателем которого является Берт Хеллингер. Психотерапевтическая работа в данном методе охватывает содержание бессознательного на трех уровнях: личном, родовом и коллективном бессознательном. Каждый из этих уровней имеет свою определенную символику, пониманием которой должен владеть психотерапевт, работающий в данном направлении психотерапии. Одним из основополагающих механизмов работы метода системных семейных расстановок является работа с символами и образами, которые отражают те или иные структуры психики. В процессе проведения психотерапевтического сеанса у клиента или у заместителей при групповой работе возникают переживания, которые отражают динамику в бессознательных структурах психики клиента. Аналогично с другими методами, язык бессознательного клиента отражается через символы, образы, фантазии, метафоры, на базе которых терапевт выстраивает стратегию сеанса. В методе системных семейных расстановок большое внимание уделяется взаимосвязям между структурами психики, которые Б. Хеллингер называет «порядками любви». Порядки любви - это те законы и закономерности, на базе которых строятся взаимосвязи между структурами психики человека. Эти взаимосвязи могут быть в нормальном состоянии, и тогда человек чувствует себя целостным и интегрированным, а могут быть нарушены, что вызывает симптоматику или проблему. Б. Хеллингер выделяет в психике человека множество таких связей или «порядков любви». Основные «порядки любви» и их нарушения возникают во взаимоотношениях между родителями и детьми, между мужьями и женами, братьями и сестрами, мужчинами и женщинами. Симптомы, как правило, символически отражают противоречие между внутренними переживаниями и поведением, например, внутреннее переживание основано на непринятии кого-либо, тогда как внешне это не демонстрируется. Работая с проблемой или симптомом в методе системных семейных расстановок терапевт стремится устранить подобное противоречие и таким образом трансформировать негативную связь (порядок любви) в конструктивную. Символами конструктивных связей являются чувства уважения и принятия к другим людям.

КЛЮЧЕВЫЕ СЛОВА: системные семейные расстановки, бессознательное, символы, метафора, порядки любви, инсайт, эмоциональное отреагирование. 